\title{
Bibliography of Pharmaceutical Research
}

\author{
Conducted by H. V. Arny, Reporter on the Progress of Pharmacy, Chairman of the \\ Committee on Research.
}

On these pages, each month, will be found a list of articles on pharmaceutical research; the list appearing a certain month will record articles appearing in American journals of the preceding month and articles appearing in foreign journals will be recorded as quickly as possible aiter the journals reach the Reporter.

All articles appearing in these lists will be presented in abstract form in the bound volumes of the YEAR BOOK which will be issued as soon after the end of the year represented as editing and printing conditions permit. Those desiring abstracts immediately can obtain same for a fee of one dollar each by communicating with H. V. Arny, 115 West 68th St., New York, and arrangements can also be made for securing photographic reproductions of entire articles at moderate prices when such are desired.

PHARMACOPOEIAI, REVISION.

Brurner, G. I:

Alkaloidal assays of the Swiss Pharmacopoeia Schweiz. A poth. Ztg., 60 (Mar. 30, 1922), 169

PHARMACEUTICAL PREPARATIONS.

Anon

Concentrated infusion of ipecac

Pharm. Monatsh.; through Pharm. Zent., 63 (Mch. 30, 1922), 181

Anon

Storing bay rum

Pharm. Era, 55 (Apr. 1922), 130

Astruc, A., Canals, E., and Bordier, R.

Alkaloidal assay of extract of aconite

$J$. pharm. chim., 25 (Mch. 1, 1922), 161

Beyer, G. F.

Assaying esters in imitation flavoring extracts

J. Ind. Eng. Chem., 14 (Apr. 1922), 324

Breteau, P.

Wound lotion

J. pharm. chim., 25 (Feb. 1, 1922), 98

Büchmann, E.

Dichlorethylene in assays of extract of cinchona

Pharm. Ztg., 67 (Mch. 15, 1922), 228

Coppez

Cholesterol in ointments

Clin. ophlal.; through Drug Circ., 66 (Apr. 1922), 144

Couch, J. F.

Rate of extraction of cascara sagrada

Am. J. Pharm., 94 (Mch. 1922), 168

Dubucquet, L.

Adrenaline solutions for injection

J. pharm. chim., 25 (Feb. 16, 1922), 136

Goris and Kosty

Extract of belladonna

Bull. sci. pharmacol.; through Drug. Circ., 66 (Apr. 1922), 143
Helferich, B.

Two new methyl glucoside derivatives

Ber.; through $J$. pharm. chim., 25 (.Mch. I, 1922), 182

Herissey, H., and Delauncy, P.

Adrenaline solution for injection

J. pharm. chim., 25 (Feb. 1, 1922), 118

Jones, E. R.

Hajr tonic recipes

Bull. pharm., 36 (Mch. 1922), 96

Jones, E. R.

Hand and face lotion remedies

Bull. pharm., 36 (Apr. 1922), 162

Jones, F. R.

Soluble compound spirit of orange for aromatic elixir

J. Am. Pharm, Assoc, 11 (Apr. 1922), 277

Jones, E. R.

White precipitate ointment by the wet process J. A. Pharm. Assoc., 11 (Apr. 1922), 278

Jung, E.

Dispensing notes

Pharm. Ztg., 67 (Mch. 22, 1922), 252

Keane, A. H. J.

Formaldehyde soaps

Sci. Am.; through Nat. Drug., 52 (Mch. 1922), 104

Kloeven

Prevention of cloudiness in vinegar of sabadilla

A poth. Ztg.; through Pharm. Zent., 63 (Mch. $23,1922), 177$

Konrich

Relative value of commercial venereal prophylactics

Pharm. Ztg., 67 (March 8, 1922), 202

Lyons, A. B.

Detection of diethylphthalate in whiskey

J. Am. Phiarm. Assoc., 11 (Apr. 1922), 262 
Murray, M. A.

Witches' ointments

Am. J. Pharm., 94 (Mch. 1922), 212

Sagi, F. and A.

Preparation of solutions of unstable substances

Berl. klin. Wsch.; through Pharm. Zig., 67 (Feb. 25, 1922), 165

Stich, C.

Dispensing notes

Pharm. Zent., 63 (Mch. 30, 1922), 179

Toulant

Ointment bases in eye troubles

Le Médecin; through Pharm. J., 108 (Mch. 11, 1922), 196

Tunger

Ointment for burns

Disch. med. Wsch.; through Pharm. Zent., 63 (Mch. 15, 1922), 159

\section{GFINERAL BOTANY AND BACTFRIOLOGY.}

Claassen, L. P. W.

Insect enemies of Typha latifolia

Am. J. Pharm., 94 (Mch. 1922), 207

Heilbron, I. M

Fhoto- and phytosynthesis of plant products

J. Soc. Chem. Ind., 41 (Mch. 15, 1922), 89R

Hess, I., and Reitler, R.

Action of metals on sera

Biochem. Zsch.; through J. Soc. Chem. Ind., 41 (Mch. 15, 1922), 194A

Levaditi and Harvier

Purity of vaccine lymph

Pract. Drug., 40 (Apr. 1922), 34

Neuberg and Arinstein

Synthesis of fats in plants

Chem. L'mschau; through Pharm. Zent., 63 (Mch. 9, 1922), 141

Vincent, $\mathrm{H}$.

Anti-dysenteric vaccination

J. pharm. chim., 25 (Feb. 1, 1922), 115

'THERAPEUTICS AND NEW REMEDIFS

Anon

R. 767

Z. physiol. Chem.; through Pharm. Zent., 63 (Mch. 9, 1922), 142

Anon

\section{Tonophosphan}

Therap. Gegenv.; through Pharm. Zent., 6:3 (Mch. 2, 1922), 131

Rojahn, C. A.

Sphragid

Apoth. Ztg.; through Pharm. Zent., 63 (Mch. $15,1922), 153$

Stephan

Ferrozym

Pharm. Ztg., 67 (Mch. 1, 1922), 177
VEGETABIE AND ANIMAL MATERIA MFDICA

Arnold, R.

The glucose of viburnum, of cinchona and of kola

J. pharm. chim., 25 (Feb. 1, 1922, 116

Bode, G., and Hembd, $K$.

Manganese content of potatoes

Biochem. Zsch.; through Pharm. Ztg., 67 (Feb. $22,1922), 157$

Borsche, W., and Roth, A.

Resin of kava kava

Ber.; through Am. J. Pharm., 94 (Mch. 1022), 206

Brand, W., and Wolff, M.

Testing anise

Ber. disch. pharm. Ges., 32 (Feb. 1922), 34

Dawe, M. T.

South American ginger

Nat. Drug., 52 (Apr. 1922), 163

Holde and Bleymann

Ukuhuba fat

Chem. Umschau; through Pharm. Zent., 63 (Mch. 30, 1922), 186

Iauro, M. F., and Dickhart, W. H.

Refining palm oil

Am. J. Pharm., 94 (Apr. 1922), 245

I, itterscheid, F. M.

Detecting commercial invert sugar in honey

Z. Unters. Nahr.-Genussm.; through Pharm. $J ., 108$ (Mch. 18, 1922), 221

Markwalder, J.

Pharmacologic value of squill

Klin. Wsch.; through Pharm. Zent., 6:3 (Mch. 15. 1922), 160

Nestler, A.

Adulterated marjoram

Pharm. Zent., 63 (Mch. 9, 1922), 137

Neuberg, C., and Ohle, $H$.

Sulphur content of agar

Biochem. Zsch.; through Pharm. Ztg., 67 (Feb. 22, 1922), 156

Prax, $]$.

Detecting sesame oil in olive oil

Ann. Falsif.; through Pharm. Ztg., 67 (Feb. $22,1922), 156$

Reko

Peyotl or mescal button

Janus; through Pharm. Ztg., (j7 (Feb. 25, 1922), 165

Russell, G. A.

Influence of distillation method on quality of oil of chenopodium

J. Am. Pharm. Assoc., 11 (Apr. 1922), 255

Sabalitschka, 'T., and Riesenberg, $H$.

Powdered mushrooms and yeast extracts

Ber. disch. pharm. Ge:, 32 (Feh. 1922), 48 
Sherwood, C. M.

Naval stores from dead pine trees

Chem. Met. Eng.; through J. Soc. Chem. Ind., 41 (Mch. 15, 1922), 101R

Suppan, $\mathrm{I}$

Dioscorides and Pliny on opium

Nat. Drug., 52 (Mch. 1922), 110

Suppan, I.

Sarcocolla

Nal. Drug., 52 (Apr. 1922), 153

Van Zijp, C.

Presence of cantharidin in Cessites maxillosa

Pharm. Weekbl., 59 (Mch. 25, 1922), 285

Wadsworth, R. V.

Theobromine content of cacao bean

J. Soc. Chem. Ind., 41 (Mch. 15, 1922), 99R

GENERAL AND PHYSICAL, CHEMISTRY.

Baker, H. B.

Change of properties on drying

Chem. \& Drug., 96 (Mch. 25, 1922), 391

Christiansen, W. G.

Sulphur content of arsphenamine

J. A m. Chem. Soc., 44 (Apr. 1922), 847 and 854

Clark, G. L.

Application of geometry to inorganic chemistry

Science, 55 (Apr. 7, 1922), 401

Evers and Gamble

Acidity and alkalinity

Pharm. J., 108 (Mch. 4, 1922), 175

Guillaumin, C. O.

Colorimetric determination of hydrogen ions in biologic fluids

J. pharm. rhim., 25 (Mch. 1, 1922), 173 and (Mch. 16, 1922) 221

Kleemann

Use of hydrogen dioxide in Kjeldahl assays

Chem. Ztg.; tbrough Pharm. Zent., 63 (Feb. $23,1922), 113$

Meillere, N., and St. Rath

Modified Kjeldahl apparatus

J. pharm. chim., 25 (Feb. 1, 1922), 100

Moreu and Dufraisse

Anti-oxidation bodies

Chem. \& Drug., 96 (Mch. 25, 1922), 376

Skita, A.

Catalytic hydrogenation

Ber.; through $J$. Soc. Chem. Ind., 41 (Mch. $15,1922), 195 \mathrm{~A}$

\section{INORGANIC CHEMICALS.}

Artault de Vevey, S.

Intramuscular injections of magnesium sulphate

J. pharm. chim., 25 (Mch. 1, 1922), 194

Broeksmit, T. C. N.

Zinc borate

Pharm. Weekblad, 59 (Mch. 18, 1922), 265
Coutière, $\mathrm{H}$.

Inhalation of calcium compounds in tuberculosis

Bull. Acad. Med. Paris; through Pharm. J., 108 (Mch. 18, 1922), 221

Czochralski, J.

Silumin, a new light alloy

Z. Metallk.; through J. Soc. Chem. Ind., 41 (Mch. 31, 1922), 219

Escaich

Detecting nitrates and nitrites in water

Rep. Pharm.; through Pharm. Zent., 63 (Mch. 30, 1922), 181

Heiduschka, A.

Action of water on glass

Pharm. Zent., 63 (Mch. 9, 1922), 138

Joachimoglu, G., and Hirose, W.

Pharmacology of selenium and tellurium

Biochem. Zsch.; through J. Soc. Chem. Ind., 41 (Mch. 31, 1922), 231A

Kolthoff, I. M.

Argentometric titration of phosphoric acid

Pharm. Weekbl., 59 (Mch. 4, 1922), 205

Lapierre, C.

Nitrates in the spring water of Ericeira

Chem. \& Drug., 96 (Mch. 18, 1922), 348

Lutz, $O$.

Sensitivity of strontium reactions

Z. anal. Chem.; through J. Soc. Chem. Ind., 41 (Mch. 15, 1922), 200A

Macheleidt

Volumetric assay of potassium

Woch. Brau.; through J. Soc. Chem. Ind., 41

(Mch. 15, 1922), 200A

McClendon, J. F.

Are iodides foods?

Science, 55 (Apr. 7, 1922), 358

Merklen, Dubois-Roquebert and Turpin

Intravenous injections of calcium chloride in tubercular diarrhea

J. pharm. chim., 25 (Mch. 1, 1922), 194

Metzger, F. J.

Practical uses of neon

Am. Drug., 70 (Mch. 1922), 15

Ransome, F. L.

Quicksilver mining in United States

Pharm. Era, 55 (Apr. 1922), 136

Robin, A.

Calcium and magnesium silicates in cancer

Chem. \& Drug., 96 (Mch. 11, 1922), 343

Wendt, G. L., and Irion, C. E.

Conversion of tungsten into helium

Pharm. J., 108 (Mch. 18, 1922), 229

Anon

ORGANIC CHEMICALS.

Manufacture of zinc stearate

Pharm. Era, 55 (Apr. 1922), 129 
Asahina, Y., and Asano, M.

Spilanthol

J. Pharm. Soc. Japan, 480 (Feb. 1922), 85

Asano, $M$.

Amides and anilides of some fatty acids

J. Pharm. Soc. Japan., 480 (Feb. 1922), 97

Astruc, A., and Renaud, E.

Chloroform and peptic digestion

J. pharm. chim., 25 (Feb. 1, 1922), 81

Azadian, A.

Silicotungstic assay of caffeine

Bull. soc. chim. Belge; through J. Soc. Chem. Ind., 41 (Mch. 15, 1922), 193A

Bailey, H. S.

Stillingia oil

Chem. Umschau; through Pharm. Zent, 63 (Mch. 2, 1922), 130

Baker, M. J. L., and Hulton, H. F. E.

The amylase of oats

$J$. Chem. Soc.; through J. pharm. chim., 25 (Jan. 16, 1922), 66

Hamberger, M., Janke, A., and Schluck, G.

Alcohol from asphodel tubers

Oesterr. Chem. Ztg.; through J. Soc. Chem. Ind., 41 (Mch. 15, 1922), 190A

Baudisch, O., and Johnson, T. B.

Detection of thymine

Ber.; through J. Soc. Chem. Ind., 41 (Mch. $15,1922), 194 \mathrm{~A}$

Bennett, A. H., and Donovan, F. K.

Hydroxylamine assay of aldehydes and ketones

J. Soc. Chem. Ind., 41 (Mch. 15, 1922), 99R

Boldue, A. G.

Picric acid as an antiseptic

I. Ind. Hygiene; through Pharm. Era, 55 (Apr. 1922), 132

Bonwetsch, $\mathbf{T}$.

Colorimetric assay of invert sugar

Pharm. Weekbl., 59 (Mch. 4, 1922), 216

Breteau, $P$.

Solution of novocaine and adrenaline as local anesthetic

J. pharm. chim., 25 (Feb. 1, 1922), 97

Bridel, M.

Action of emulsin on lactose in 80 percent, alcohol

J. pharm. chim., 25 (Feb. 16, 1922), 129

Clark, E. P.

Preparation of galactose

Chem. Trade J.; through Pharm. J., 10 (Mch. 11, 1922), 192

Curme, G. E.

Ethylene dichloride

Chem. Met. Eng.; through Pract. Drug., 40 (Apr. 1922), 34
Dupont, G.

Oil of turpentine from aleppo pine

Compt. rend.; through J. Soc. Chem. Ind., 41 (Mch. 31, 1922), 223A

Eder, R., and Widmer, C.

Synthesis of chrysophanic acid

Helv. Chim. Acta.; through J. Soc. Chem. Ind., 41 (Mch. 15, 1922), 194A

Fichter, F., and Lowe, $\mathrm{H}$.

Saccharin from ortho-toluene sulphonamide

Helv. Chim. Acta; through J. Soc. Chem. Ind., 41 (Mch. 15, 1922), 195A

Gorter, K.

Laurotetanine

Bull. Jard. Bot. Buitenzorg; through J.pharm. chim., 25 (Feb. 16, 1922), 149

Graybeal, A. C., and Kremers, R. E.

Preparation of amido-phenol from $d$-limonene

J. Am. Pharm. Assoc., 11 (Apr. 1922), 252

Haas, $\mathbf{P}$.

Carbohydrates in present day economy

Pharm. J., 108 (Mch. 18, 1922), 222

Hanek

Sugar assay

Z. Unters. Nahr. Genussm.; through Drug. Circ., 66 (Apr. 1922), 144

Helferich, B.

Preparation of emulsin

$Z$. physiol. Chem.; through J. Soc. Chem. Ind., 41 (Mch. 31, 1922), 228A

Huerre, R.

Role of wood tissues in production of oil of cade

J. pharm. chim., 25 (Mch. 1, 1922), 165 and (Mch. 16, 1922), 214

Kolthoff, I. M.

Detecting levulose in aldose mixtures

Chem. Weekbl.; through $J$. Soc. Chem. Ind., 41 (Mch. 15, 1922), 188A

Kryz

Color test for sucrose

Oesterr. Chem. Ztg.; through J. Soc. Chem. Ind., 41 (Mch. 15, 1922), 188A

Lange, $B$.

Antiseptic value of cresol in aqueous and soap solutions

2. Hyg. Infect.- Krankh.; througb J. Soc. Chem. Ind., 41 (Mch. 15, 1922), 193A

Lax, H.

Vitamine of cod liver oil

Biochem. Zsch.; through J. Soc. Chem. Ind., 41 (Mch. 31, 1922), 230A

I,eech, P. N.

Acetylsalicylic acid in sodium citrate solution J. Am. Med. Assoc.; through J. Am. Pharm. Assoc., 11 (Apr. 1922), 275 
Lewis, S. J.

Proteins of blood sera

Chem. \& Drug., 96 (Mch. 25, 1922), 391

Leys, A.

Rapid determination of the acetyl number of fats

J. pharm. chim., 25 (Jan. 16, 1922), 49

Lowry and Cutter

Preparation and properties of ethyl tartrate

Chem. \& Drug., 96 (Mch. 11, 1922), 324

Lumiere, A., and Couturier, $\mathrm{H}$.

Sodium oleate in shock

Compt. rend.; through J. pharm. chim., 25

(Mch. 1, 1922), 192

Moureau, C., and Dufraisse, C.

Auto-oxidation of organic bodies

Compl. rend.; through J. Soc. Chem. Ind., 41 (Mch. 15, 1922), 195A

Parsons, L. W., and Wilson, R. E.

Color standards for oils

J. Ind. Eng. Chem., 14 (Apr. 1922), 269

Pfyl, B., Reif, G., and Hanner, A.

Glycerides of goose grease

$Z$. Lnters. Nahr-Genussm.; through Pharm. Ztg., 6r (Feb. 22, 1922), 156

Ponder, E.

Hemolytic action of sodium glycocholate

Proc. Roy. Soc.; through J. Soc. Chem. Ind., 41 (Mch. 31, 1922), 231 A

Pottie $\%$, C.

Phenolphthalein

$J$. pharm. Belg.; through J. pharm. chim., 25 (Feb). 16, 1922), 150

Pringsheim, H., and Aronowsky

Inulin

Ber.; through J. pharm. chim., 25 (Mch. 1, 1922), 18:3

Pschorr, Pfaff and Berndt

Saponification number and acid number of dark oils and waxes

Chem. Lmschau; through Pharm. Zent, 63 (Mch. 15, 1922), 153

Raiziss, G. W.

Organic nitro compounds containing mercury

J. Am. Chem. Soc., +4 (Apr. 1922), 787

Rodillon, G.

Cause of error in the $o$-nitrophenyl propionic assay of glucose

J. pharm. chim., 25) (Jan. 16, 1922), 56

Rosenmund, K. W., and Zetsche, F.

Influence of catalysts on the oxidation of alcohols

Ber.; through Pharm. Zent., 63 (Mch. 22, (1922), 170

Sage, C. E., and Gondale, A.

Spanish fennel oil

Perf. Essent. Oil. Rec.; through J. Soc. Chem. Ind., 41 (Mch. 15, 1922), 197A
Stepp, W., and Friche, R.

Simple aldehyde assay

$Z$. physiol. chem.; through J. Soc. Chem. Ind., 41(Mch. 15, 1922), 197 A

Sumner, J. B., and Graham, V. A.

Dinitrosalicylic acid in glucose assays

$J$. Biol. Chem.; through $J$. pharm. chim., $2 \tilde{j}$ (Mch. 16, 1922), 230

Tutin, $\mathbf{F}$

Action of alkalies and pectase on pectin

Ber.; through J. pharm. chim., 25 (Mch. 1, 1922), 183

Twitchell, F.

Precipitation of fatty acids with lead acetate

Z. Oel. Fetl. Ind; through Pharm. Zlg., 67 (Feb. 22, 1922), 156

Utz, F.

Solubility of veronal in chloroform

Pharm. Zent., 63 (Mch. 30, 192?), 180

Williams, R. C.

Synthesis of guaiacol

Pharm. Era, 55 (Apr. 1922), 13i)

Willstater, R., and Csanyi, W.

Hydrolytic action of emulsin

$Z$. physiol. Chem.; through J. Soc. Chem.Ind., 41 (Mch. 31, 1922), 228A

Winterstein, E., and Iatrides, D.

Taxine from the yew tree

J. Soc. Chem. Ind., 41 (Mch. 31, 1922), 230A

Zangger, $\mathrm{T}$.

Veronal in seasickness

Lancet.; through $A \mathrm{~m}$. Drug., 70 (Apr. 1922), 16

Zechner, $\mathrm{L}_{\text {., }}$ and Wischo, $\mathrm{F}$.

Tests for adrenaline

Pharm. Monatsh.; through J. Soc. Chem. Ind., 41 (Mch. 15, 1922), 194A

\section{CLINICAL AND DIAGNOSTIC METHODS.}

Anon

Micro-determination of the density of urine

Arch. Kinderheil.; through Am. Drug., 70 (Mch. 1922), 40

Clogne, $\mathrm{R}$.

New form of ureometer

J. pharm. chim., 25 (Feb. 1, 1922), 99

Eticnne, G., and Verain, $M$.

Assay of glucose in body fluids

Compi. rend. soc. biol.; through $J$. pharm. chim., 25 (Mch. 16, 1922), 228

Thiéry

The Folin assay of uric acid

$J$. pharm. chim., 25 (Feb. 1, 1922), 87

Thiéry

Zinc-potassium ferrocyanide as defecating agent for blood

J. pharm. chim., 25 (Mch. 16, 1922), 209 
Van Eck, P. N.

Micro-chemical examination of feces

Pharm. Weekblad, 59 (Mch. 11, 1922), 234

Williamson

Blood tests in diabetes

J. Am. Med. Assoc,; through Am. J. Pharm., 94 (Apr. 1922), 295

\section{MISCEI.LANEOUS.}

Bellwook, R. A.

New method of oil extraction

Chem. Umschau; through Pharm. Zent., 63 (Mch. 23, 1922), 171

Bruning, A.

Detecting forgery in documents

Ber. disch. pharm. Ges., 32 (Feb. 1922), 30

Ditmar

Celluloid caoutchouc
Chem. Ztg.; through Pharm. Weekblad, 59 (Mch. 25, 1922), 294

Gattefossé

Extraction process in perfume production

Kiv. Ital. Ess. Prof.; through J. Soc. Chem. Ind., 41 (Mch. 31, 1922), 231A

Gawalowski, A.

Aluminum flash light

D. A. A poth. Ztg., 43 (Mch. 1922), 4

Jacobs, R. L.

Automobile polishes

Bull. Pharm., 36 (Apr. 1922), 152

Mitchell, C. H.

Chemistry of inks

J. Soc. Chem. Ind., 41 (Mch. 15, 1922), 92R

Sayre, L. E.

Beverages and fruit flavors

Am. Drug., 70 (Mar. 1922), 24

\section{ProceEDINGS OF THE LOCAL BRANCHES}

"All papers presented to the Association and its branches shall become the property of the Association, with the understanding that they are not to be published in any other publication than those of the Association, except by consent of the Committee on Publication."-By-Laws, Chapter X, Art. III.

Reports of the meetings of the Local Branches should be mailed to the Editor on the day following the meeting, if possible. Minutes should be typewritten, with wide spaces between the lines. Care should be taken to give proper names correctly, and manuscript should be signed by the reporter. To maintain its activity and representation each Branch should see that at least three of its meetings during the year are reported in the JourNaL.

\section{BAITIMORE.}

The March meeting of the Baltimore Branch of the American Pharmaceutical Association was held at the Fimerson Hotel on March 22, 1922 .

Dr. Hermann Engelhardt, the newly elected President of the Branch, in his opening remarks greeted the Branch as their leader for the ensuing year. There was a good attendance.

Dr. E. F. Kelly, as chairman of the Committee on Legislation and Education, explained the splendid progress of the bills in the Mary. land Legislature dealing with the positions of the pharmacists and the State Board of Health. Emphasis was laid on the most unusual coöperation of the pharmacists in the state in supporting these measures.

The main feature of the evening was an address by Dr. Neil E. Gordon, head of the Department of Chemistry of the University of Maryland. The title of the address was "Eimulsification and Absorption." The spcaker made clear the theory of emulsification from the standpoint of the physical chemist and colloidist, and laid particular stress on the three phases of the usual pharmaceutical emulsions. The permanency of emulsions was discussed at great length, and slides were used to illustrate the stability of emulsions made with various emulsifying agents. At this point the lecturer introduced Fisher's so-called "Hydrate Theory" of emulsification, which holds that the soluble phase of the three phase emulsion forms with water a large hydrate, thus modifying the properties of the water to the extent of more or less permanently suspending the insoluble phase. The " $\mathrm{Hy}$ drate Theory" explains that the breaking of emulsions by the addition of saline solutions is due to the neutralization of the charge on the hydrate by the electrolyte.

Under "Absorption" Ir. Gordon discussed some of the research work in which he was engaged, establishing a ration between the hydrogen ion concentration of absorption of many substances, including iron, aluminum and silica jells.

Following the lecture an exceedingly interesting discussion took place, in which $H$. $H$. 